\title{
APLIKASI EDRAW MIND MAP BAGI GURU SD NEGERI O50702 KECAMATAN SECANGGANG KABUPATEN LANGKAT
}

\author{
Mardiah $^{1)}$, Hendra ${ }^{2)}$, Nina Hastina ${ }^{2)}$ \\ 1) Sistim Informasi, Universitas Nahdlatul Ulama Sumatera Utara, \\ 2) Pendidikan Guru Sekolah Dasar, Universitas Nahdlatul Ulama Sumatera Utara, \\ e-mail: mardiahindin23@gmail.com
}

\begin{abstract}
The purpose of the training activities on the use of the Edraw Mind Map application is that teachers are expected to have an increase in their professional and pedagogical abilities in implementing learning in schools, especially learning to write learning materials by their students. Using the media learning, mind mapping is one of the efforts made to improve and enhance students' abilities and motivation in writing learning material. The Edraw Mind Map application is one of the most simple and easy-to-use applications for teachers who must be able to keep up with current technological developments. With the use of this application, the teacher can make a summary of the learning notes into a mind mapping and can apply them to students so that students have a new way that is more fun in terms of writing or taking notes using mind mapping that uses lines, branch lines, keywords, colours and images. The community service will be held from May to September 2019 with 19 visits. The results of this community service implementation are easier for masters to make mind mapping manually using colouring paper and stationery than using an application. However, teachers can also use the Edraw Mind Map application. The teacher's ability to create mind mapping on the blackboard and applications can be applied to the student so that students have also been able to convert a lot of writing into a shorter and more fun mind mapping.
\end{abstract}

Keywords: Edraw Mind Map Application, Teacher, Students, Writing

\begin{abstract}
Abstrak
Tujuan kegiatan pelatihan penggunaan aplikasi Edraw Mind Map ini diharapkan guru memeliki peningkatan kemampuan profesional dan pedagogiknya dalam pelaksanaan pembelajaran di Sekolah, khususnya pembelajaran menulis materi pembelajaran oleh siswanya. Menggunakan salah satu media pembelajaran yaitu mind mapppping merupakan salah satu usaha yang dilkaukan untuk memperbaiki dan meningkatkan kemampuan serta motivasi siswa dalam menulis materi pembelajaran. Aplikasi Edraw Mind Map merupkan salah satu aplikasi yang paling sederhana dan mudah digunakan guru yang harus mampu mengikuti perkembangan teknologi sekarang. Dengan pemanfaatan aplikasi ini guru dapat membuat sebuah ringkasan catatan pembelajaran menjadi sebuah mind mappping dan dapat menerapkannya ke siswa sehingga siswa mempunyai cara baru yang lebih menyenangkan dalam hal menulis atau mencatat menggunakan mind mapping yang menggunakan garis,garis cabang, kata kunci, warna dan gambar. Pelaksanaan pengabdian ini dilaksanakan mulai bulai Mei hingga September 2019 dengan jumlah kunjungan pelaksanaan 19 Kunjungan. Hasil pelaksanaan pengabdian ini guru-guru lebih mudah menguasai pembuatan mind mapping secara manual menggunakan kertas dan alat tulis mewarnai dari pada menggunakan sebuah aplikasi. Namun, guru juga dapat menggunakan aplikasi Edraw Mind Map. Kemampuan guru dalam membuat mind mapping di papan tulis dan aplikasi dapat diterapkan guru ke sisiwa sehingga siswa juga telah mampu mengkonversikan sebuah tulisan yang sangat banyak menjadi lebih singkat dan menyenangkan dalam mind mapping.
\end{abstract}

Kata Kunci : Aplikasi Edraw Mind Map, Guru, Siswa, Menulis

\section{PENDAHULUAN}

Lokasi mitra berada di kecamatan Secanggang Kabupaten Langkat Provinsi Sumatera Utara. SDN SDN 050702 desa
Kepala Sungai awalnya merupakan mitra Program studi Pendidikan Guru Sekolah Dasar Universitas Nahdlatul Ulama Sumatera Utara yang menjadi mitra 
tempat lab praktek KKN mahasiswa dalam pelaksanaan praktek kompetensi pedagogiik. SDN ini terdapat 6 rombongan belajar dalam setiap jenjang kelas dan di setiap kelas jumlah murid rata- rata 20 siswa dalam setiap kelas. Tenaga pengajar ada 6 guru kelas dan 3 guru bidang studi yaitu guru Agama, Pendidikan Jasmani Kesehatan dan Guru Bahasa Inggris. Kegiatan pembelajaran dan kehidupan pembelajaran di sekolah ini berlangsung seperti biasa sekolah pada umumnya dengan aturan kurikulum yang ada di pemerintah dinas pendidikan. Kegiatan pembelajaran dengan aktivitas menyimak, membaca, menulis, mengamati, berbicara, melakukan demostrasi di kelas melalui pemebelajaran tematik dan pembelajaran bidang studi dilaksanakan di SDN ini. Namun , ada satu aktivitas yang menjadi perhatian yaitu aktivitas pembelajaran guru menyampaikan ilmu pengetahuan dengan metode ceramah penejelasan dan catatan guru di papan tulis serta buku siswa yang disalin ulang oleh siswa untuk mendapatkan pemahaman ulang dari hasil menyimak penjelasan guru dan bermanfaat untuk menyimpan pengetahuan yang sudah dipelajari dalam bentuk catatan di buku catatan siswa. Aktivitas menulis tersebut memindahkan materi pembelajaran yang disampaikan oleh guru dan buku pegangan siswa kedalam buku catatan siswa masih dalam bentuk yang sama tulisan dengan paragraph. Hal ini tidak lebih memudahkan siswa untuk lebih memahami isi materi pembelajaran dengan memindahkan tulisan ke dalam catatan. Postur tubuh siswa saat menyalin dengan postur tubuh yang malas dan tidak bersemangat. Menyalin dengan pandangan dan pikiran yang kurang aktif sehingga aktivitas ini menurut siswa sangat tidak menyenangkan. Pentingnya aktivitas menulis ini juga sependapat dengan pernyataan (Sholeh dan Afriani : 2017), “ Keterampilan menulis penting diajarkan karena dengan keterampilan itu siswa akan mampumengembangkan kemampuan berfikirnya, meningkatkan kecerdasan, mengembangkan daya inisiatif dan kreativitas, serta menumbuhkan keberanian kedalam bentuk tulisan dan karangan."

Oleh sebab itu, ingin dilaksanakan Program Kemitraan Masyarakatyaitu guru untuk dapat menerapkan model dan tehnik menulis dan mencatat isi materi pembelajaran dengan menggunakan mind mapping secara tradisional dan dengan menggunakan aplikasinya berbasis teknologi. (Hastina, N : 2016), "Model pembelajaran mind mapping merupakan strategi untuk mencatat materi pelajaran dengan menggunakan otak kiri, otak kanan, warna, gambar, serta simbol dalam proses pembuatannya. Mind Mapping merupakan cara memetakan pemikiran dalam bentuk gambar yang disusun dalam radial (memecar). " dengan model menyalin yang menggunakan kedua otak berkreasi dengan garis memecar, menulis dengan kata-kata kunci, menggunakan pinsil warna untuk membuat simbol/gambar sederhana dan mewarnai garis serta kata kunci tersebut menjadikan aktivitas menulis menyenangkan dan lebih mudah memahami hasil salinan catatan siswa di buku catatan berbeda dari tulisan-tulisan paragraph penjelasan di buku pegangan siswa. Tulisan menggunakan mind mapping menulis catatan dengan ringkas, menyenangkan, lebih mudah paham dan lebih mudah di ingat. Hal ini didukung dengan pernyataan : (Nurasiah dan Munajat : 2018 ) "karakteristik mind mapping ini berada pada membedakan kata-kata atau gagasan, menggunakan dengan warna dan symbol. Mind mapping pada umumnya mengambil format hirarki atau cabang pohon, dengan ide-ide bercabang menjadi subbagian mereka. Peta pemikiran memungkinkan kreativitas yang lebih besar saat merekam ide-ide dan informasi, serta memungkinkan catatan untuk mengasosiasikan kata dengan representasi visual." Berdasarkan hasil pretes yang 
dilakukan dengan guru -guru yang berjumlah 9 guru dan 1 kepala sekolah, 7 guru $(70 \%)$ masih menggunakan model pembelajaran menulis yang sama dalam setiap pembelajaran dan belum mengenal dan mampu menerapkan model dan tehnik menulis catatan materi pembelajaran menggunakan mind mapping. Pretest yang dilakukan kepada siswa di kelas 4 sampai dengan kelas 6 dengan sampel siswa berjumlah 60 siswa, 43 siswa(72\%) memiliki kategori rendah motivasi belajar dan menulis. Aktivitas menulis yang biasa dilaksanakan siswa di sekolah akan menambah aktivitas menulis yang berbeda dari yang sudah dilaksanakan siswa. Siswa akan merasakan sesuatu hal yang baru dalam kegaiatan pembelajaran dan aktivitas belajarnya. Hal ini akan dapat meningkatkan motivasi belajar siswa khususnya aktivitas menulis. Diharapkan dari Program Kemitraan Masyarakatini, guru mampu menerapkan model atau tehnik menulis catatan materi pembelajaran ini menggunaka mind mapping secara tradisional dengan spidol warna warni saat menjelaskan dengan metode ceramah dan menuliskannya di papan tulis dalam bentuk cabang pohon, kata kunci, simbol/gambar dalam penyampaian isi pembelajaran materi. Selain itu, guru juga dapat membuat mind mapping melalui aplikasi edraw mind map yang sangat sederhana dan mudah dipelajari/digunakan oleh guru yang sulit dengan teknologi. Berdasarkan hasil penelitian sebelumnya oleh penulis (Hastina, N : 2016) Vol. 1 No. 1, bahwa :

“ pada kondisi awal, sebelum diadakannya tindakan (mind mapping) adalah sebanyak 13 orang (52\%) tergolong kategori rendah motivasi belajarnya, 14 orang (48\%) tergolong kategori sedang motivasi belajarnya dan tergoloing tinggi motivasinya tidak tampak, pada siklus I setelah dilakukan tindakan, 27 orang ( $100 \%$ ) tergolong sedang motivasi belajarnya sedangkan pada siklus II, tidak ada siswa yang motivasi belajarnya tergolong rendah, 6 orang $(22 \%)$ tergolong sedang motivasi belajarnya dan 28 orang (78\%) tergolong tinggi motivasi belajarnya. Model pembelajaran mind mapping dapat digunakan sebagai alternatif dalam pembelajaran PKn."

\section{METODE}

Metode pelakasanaan Program Kemitraan Masyarakat stimulus ini adalah sebagai berikut :

1. Mengenalkan mind mapping dan memberikan contoh - contoh mind mapping kepada guru-guru dan staf pengajar lainnya.

2. Mendemonstrasikan penggunaan mind mapping

3. Memberikan buku saku tutorial membuat mind mapping manual dengan penggunaan spidol untuk di papan tulis dan pinsil warna mind mapping di lembar kertas

4. Memberikan aplikasi mind mapping yang paling sederhana dan mudah bagi guru SD yaitu aplikasi edraw mind map

5. Pendampingan program kemitraan pelaksanaan bimbingan membuat mind mapping secara manual dengan materi pembelajaran yang ditentukan oleh mitra atau guru kelas/guru bidang studi dan praktek penerapan mind mapping yang telah dibuat guru sebagai mitra dalam pembelajaran

6. Pendampingan program kemitraan pelaksanaan tutorial pembuantan mind mapping dengan aplikasi sederhana yaitu edraw mind map dan praktek penerapan mind mapping berbasis teknologi dalam pembelajaran menggunakan bahan ajar mind mapping yang berbasis teknologi

\section{Partisipasi Mitra}

Partisipasi mitra dalam program kemitraan ini dengan :

1) berpartisipasi memahami transfer pengetahuan dan pemahaman yang diberikan oleh tim 
2) Melaksanakan kegiatan sesuia dengan prosedur kegiatan yang dilksanakan oleh tim

3) Berpartisipasi dalam pendampingan yang dilaksanakan tim dalam pembuatan mind mapping secara manual dan dengan menggunakan aplikasi Edraw Mind Map.

4) Berpartisipasi dalam pelaksanaan evaluasi dan refleksi dari program kemitraan yang dilaksanakan.

\section{Langkah Evaluasi dan Keberkanjutan Program}

Evaluasi dari pelaksanaan program kemitraan dan keberlanjutan program tersebut oleh mitra :

1) Guru memiliki kemampuan dalam membuat mind mapping secara tradisional dan dengan cara aplikasi berbasis teknologi

2) Guru dapat menerapkan tehnik menulis catatan dengan mind mapping dalam pembelajaran di kelas dengan siswasiwanya.

3) Guru dapat mentransfer pemahaman dan kemampuan tersebut dengan rekan guru lain di sekolah lain dalam kegiatan Kerja Kelompok Guru (KKG), gugus sekolah dan bahkan SD di lingkungan Kecamatan atau Kabupaten.Guru sebagai mitra dapat

4) selalu meningkatkan profesionalisme dalam penyediaan media pembelajaran sejenisnya.

\section{HASIL DAN PEMBAHASAN}

\section{Kegiatan koordinasi dan kunjungan perencanaan jadwal kunjungan selanjutnya dalam pelaksanaan program kemitraan masyarakat - stimulus dengan koordinasi awal dengan kepala sekolah.}

Sebelum kegiatan ini berlangsung, pihak tim sudah mengobservasi salah satu permasalahan pembelajaran menulis di SD ini. Hasil dari diskusi dengan kepala sekolah telah disepakati jadwal pelaksanaan mengikuti waktu atau jam kosong guru dari tugas kewajibannya mengajar, mengikuti kalender pendidikan dan kalender sekolah. pelaksanaan disepakati di laknsanakan di ruang guru dengan sistem mengikuti waktu di luar jam mengajar guru yaitu saat jam istirahat dan jam pulang sekolah. jika pelaksanaan pengabdian saat proses kegiatan belajar mengajar, tim pelaksana tidak boleh mengganggu kegiatan belajar mengajar tersebut yang dapat mengalihkan pusat perhatian siswa. Pelaksanaan di ruang guru dengan fasilitas meja, kursi, dan ruangan yang nyaman serta LCD yang disediakan oleh pihat tim.

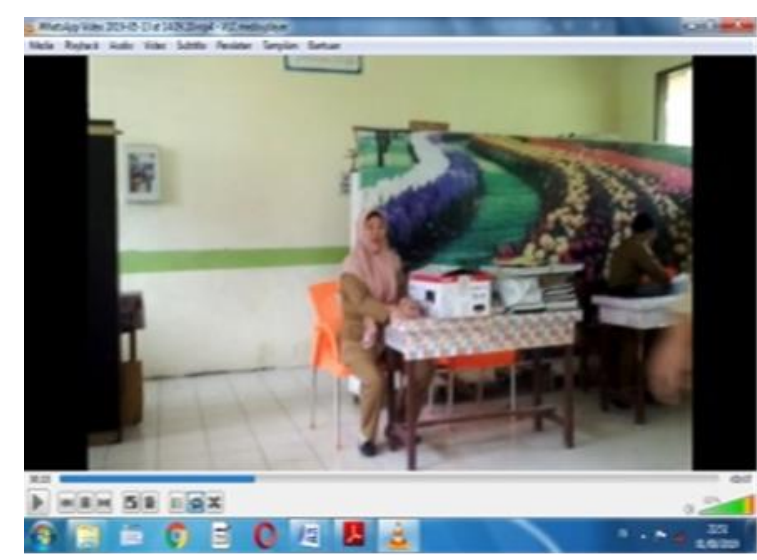

Gambar 1. Pembukaan kegiatan oleh Kepala Sekolah di Ruang Guru

\section{Persiapan perlengakapan bahan dalam pembuatan mind mapping}

Setelah hasil diskusi dan kooordinasi dengan kepala sekolah, tim mempersiapkan alat dan bahan dalam pembuatan mind mapping secara manual atau tradisional dengan menggunakan alat tulis, alat mewarnai, kertas dan papan tulis. selain bahan - bahan tersebut, tim mempersiapkan materi pembahasan untuk memaparkan perkenalan tentang mind mappping secara konseptual hingga cara membuat mind mapping secara tradisonal dengan alat tulis dan mewarnai.

Bagian hasil dan pembahasan berisi paparan hasil analisis yang berkaitan dengan pertanyaan pengabdian. Setiap hasil pengabdian harus dibahas. Pembahasan berisi pemaknaan hasil dan 
pembandingan dengan teori dan/atau hasil pengabdian sejenis. Panjang paparan hasil dan pembahasan 40-60\% dari total panjang artikel.

Persiapan bahan-bahan dan aplikasi dan instal aplikasi edraw mind map

Persiapan bahan-bahan dalam pembuatan mind mapping secara tradisional dengan menggunakan alat tulis dan mewarnai, serta flashdisk yang telah didownloadklan aplikasi edraw mind map dalam pembuatan mind mapping dengan menggunakan sebuah teknologi berupa aplikasi.

Pelaksanaan pemaparan tentang mind mapping dan aplikasi edraw mind map Pelaksanaan pelatihan dimulai dengan memaparkan atau memperkenalakan tentang mind mapping secara konseptual hingga cara pembuatan mind mapping secara tradisional terlebih dahulu dengan menggunakan kertas, papan tulis, alat tulis dan alat mewarnai terlebih dahulu sebelum cara pembuatan mind mapping dengan teknologi berupa aplikasi yaitu aplikasi Edraw Mind Map.

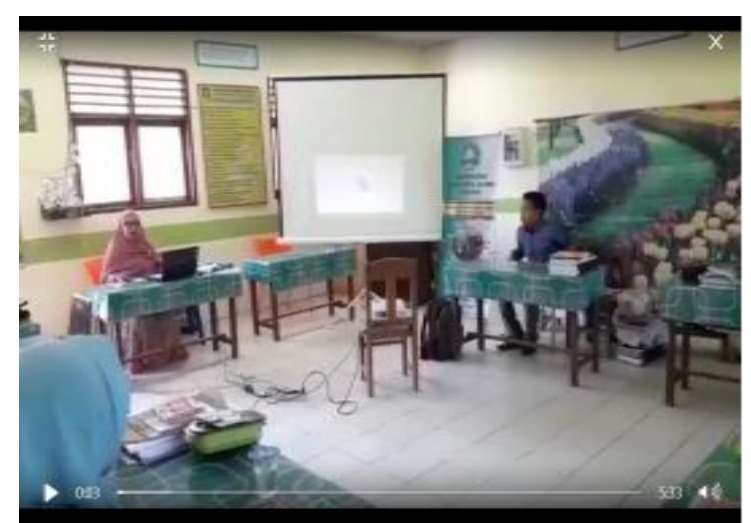

Gambar 2. Pemaparan oleh Tim

Pelaksanaan pelatihan dan bimbingan praktik pembuatan mind mapping secara tradisonal dan menggunakan aplikasi edraw mind map

Setelah mengenal dan memahami mind mapping dari konsep hingga pembuatan mind mapping secara tradisional serta perkenalan salah satu aplikasi untuk membuat mind mapping dengan teknologi untuk lebih mempermudah guru dalam menciptakan mind mapping, selanjutnya adalah kegiatan praktik langsung dalam membuat mind mapping dengan menggunakan alat tulis dan aplikasi edraw mind map.

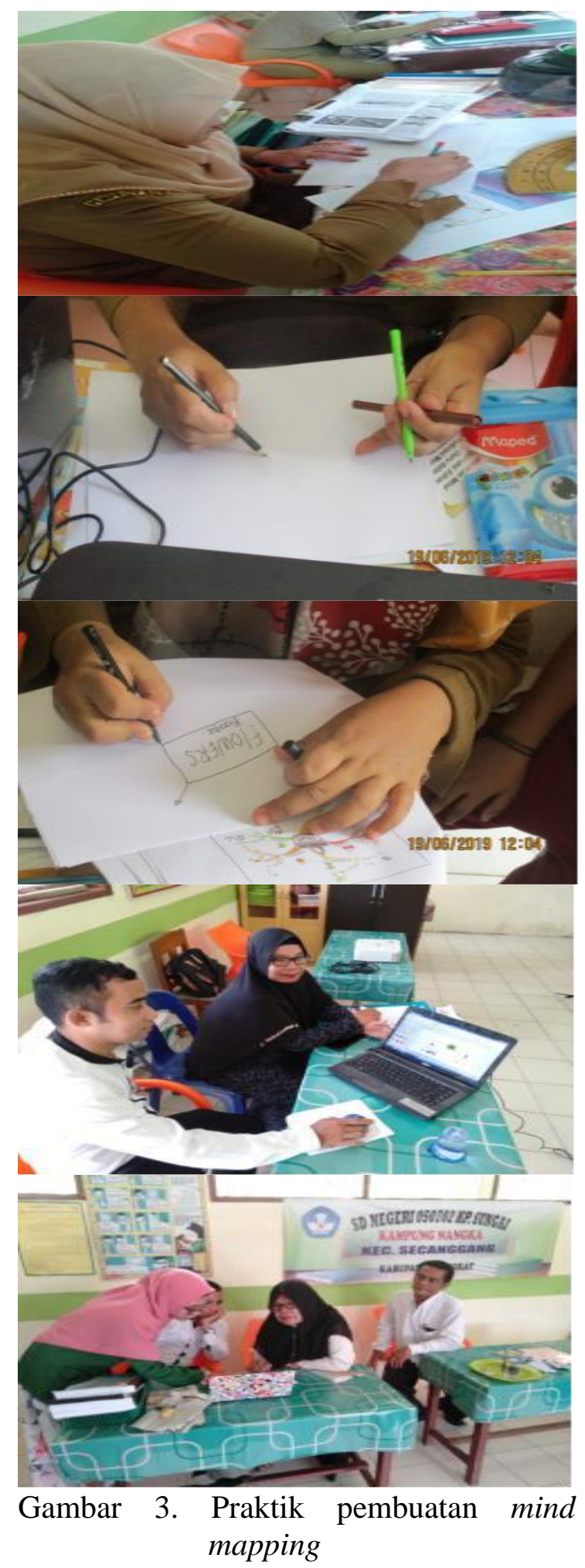




\section{Evaluasi dan Refleksi Hasil Pelatihan Praktik}

Setelah selesai kegiatan pemaparan dan pelatihan pembuatan mind mapping, guru melaksanakan kegiatan belajar mengajar dalam menulis pembelajran dengan menerapkan mind mapping baik secara tradisional maupun menggunakan aplikasi edraw mind map yang merupakan slah satu aplikasi untuk mempermufah menciptakan atau membuat imind mapping.

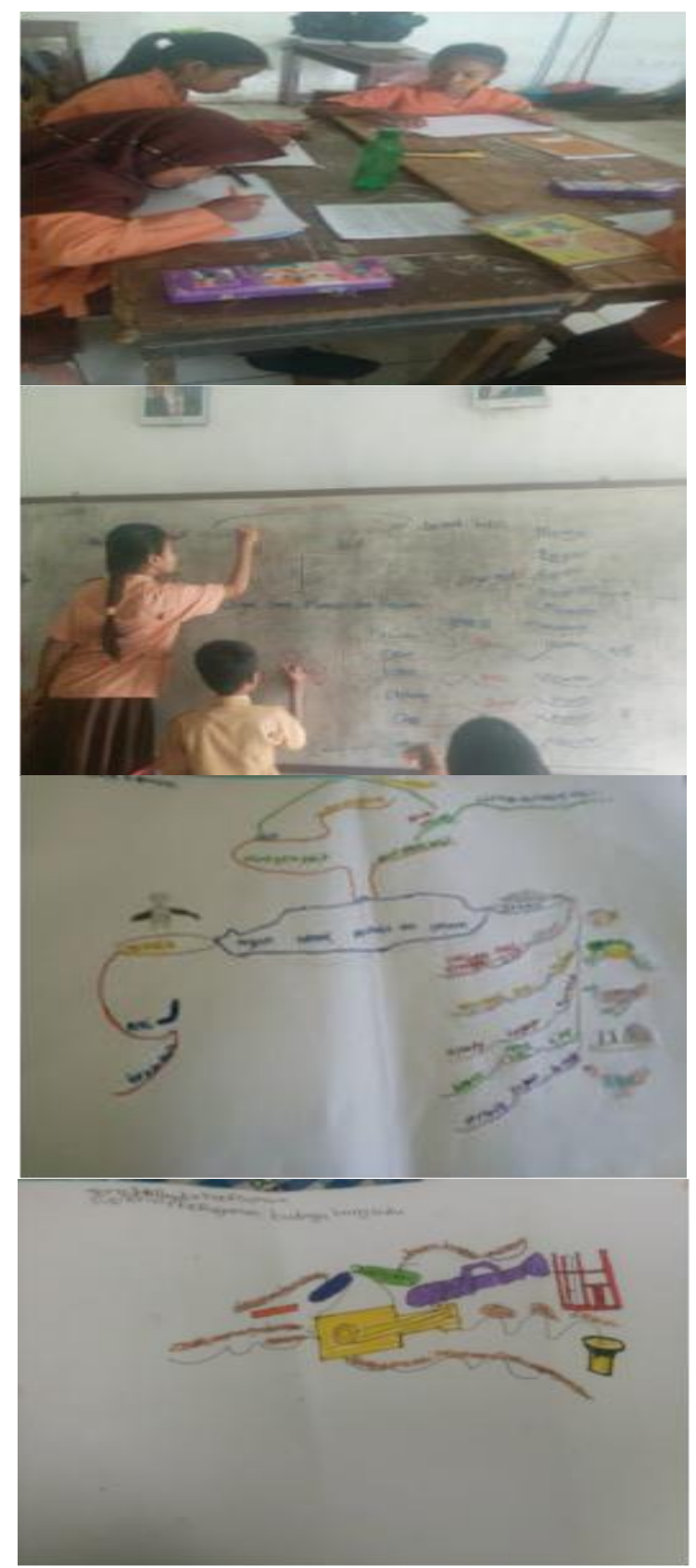

Gambar 4. Penggunaan mind mapping saat KBM

\section{SIMPULAN}

Pelaksanaan Program Kemitraan Masyarakat - Stimulus (PKM-S) dimulai dari tahap koordinasi, pengenalan dan pemaparan mind mapping dan apliksai edraw mind map hingga praktik guru dalam membuat mind mapping secara tradional pada lembar kertas dan papan tulis, mind mapping menggunakan aplikasi edraw mind map. Sehingga siswa dapat diajarkan guru juga dalam mengenal dan membuat catatan yang menyenangkan menjadi sebuah mind mapping dalam meringkas sebuah catatan materi pembelajaran.

Proses pembelajaran yang dilaksanakan oleh tim PKM-S kepada mitra yaitu guru - guru di sekolah SDN No. 050702 Kampung Nangka, diharapkan tidak berhenti setelah selesainya pelaksanaan program ini, namun tetap dilaksanakan dalam kegiatan belajar mengajar di dalam kelas kepada siswasiswa serta dapat mentransfer ilmu tersebut kepada satu gugus sekolah dalam pertemuan Kelompok Kerja Guru (KKG) baik dalam satu gugus maupun di satu kecamatan sekolah dasar lainnya sehingga lebih banyak sekolah yang mengenal dan dapat menerapkan mind mapping dalam kegiatan belajar mengajar.

\section{UCAPAN TERIMA KASIH}

Terima kasih kepada Direktorat Riset dan Pengabdian Masyarakat (DRPM) dan Kementrian Riset Teknologi dan Perguruan Tinggi (KEMENRISTEKD IKTI) untuk dukungan moril dan materil dalam pendanaan pelaksanaan dan hasil pengabdian kepada masyarakat ini.

\section{DAFTAR PUSTAKA}

Hastina, N. (2016). Motivasi Belajar Siswa Dengan Model Pembelajaran Mind Mapping. https://doi.org/10.31227/osf.io/snj wa 
Nurasiah dan Munajat. (2018). Pengembangan Pembelajaran Literasi Melalui Mind Mapping Berbasis Konstruktif Islami Untuk Meningkatkan Literasi Membaca dan Menulis Mahasiswa PGSD. Universitas Muhammadiyah Suka Bumi.
Sholeh dan Afriani. (2017). Teknik Mind Mapping Sebagai Upaya Untuk Meningkatkan Keterampilan Menulis Cerpen Pada Siswa SMA. Vol 2 No 2 